\title{
FUNCTIONING OF FARMS \\ FROM AREAS OF HIGH NATURAL VALUES AT THE BACKGROUND OF OTHER FARMS
}

\author{
MAREK ZIELIŃSKI \\ JOLANTA SOBIERAJEWSKA
}

\begin{abstract}
The paper aims at assessment of functioning of farms from gminas (municipalities) of high natural values at the background of farms from other gminas in Poland. The gminas for which the Natural and Tourism Value Index (NTVA), established by the Institute of Soil Science and Plant Cultivation - State Research Institute, amounted to at least $35.6 \%$ out of $100 \%$ possible to be achieved were considered as gminas of high natural values. The comparative analysis took into account the production potential of farms, production organization, costs incurred, productivity of factors of production, farm income per $1 \mathrm{FWU}$, share of operating subsidies in farm income and the net investment rate. The analysis was carried out using the data of farms keeping accounting for the Polish FADN in 2015 and data of the Institute of Soil Science and Plant Cultivation - State Research Institute. It was recognized that farms from areas of high natural values and keeping accounting for the Polish FADN in 2015, for instance, provided payment for the owner's and his family members' labour costs at above the parity level and saw possibilities for further development for themselves.
\end{abstract}

Keywords: farm, natural value, CAP post-2020, farm income, net investment rate.

JEL codes: Q12, Q15, Q57.

Dr inż. Marek Zieliński, Instytut Ekonomiki Rolnictwa i Gospodarki Żywnościowej - Państwowy Instytut Badawczy, Zakład Ekonomiki Gospodarstw Rolnych; ul. Świętokrzyska 20, 00-002 Warszawa (marek.zielinski@ierigz.waw.pl).

Mgr Jolanta Sobierajewska, Instytut Ekonomiki Rolnictwa i Gospodarki Żywnościowej - Państwowy Instytut Badawczy, Zakład Ekonomiki Gospodarstw Rolnych; ul. Świętokrzyska 20, 00-002 Warszawa (jolanta.sobierajewska@ierigz.waw.pl). 


\section{Introduction}

According to the findings of the European Commission (EC) to date, one of the priorities of the Common Agricultural Policy (CAP) after 2020 will be to further strengthen the role of the agricultural sector in the provision of public goods and ecosystem services by preserving and creating landscape features that stimulate biodiversity in rural areas (Komunikat Komisji, 2017; The future ..., 2017; Wäckers, 2017). From the point of view of concern about the environment, this approach of the European Commission should be considered particularly necessary ${ }^{1}$. However, a challenge of the CAP after 2020 will be to manage the process of supporting the natural values of rural areas to minimise the potential negative effects on the competitiveness of farms. It should be emphasised that despite the fact that rural areas with a varied landscape allow for maintaining many species of flora and fauna on them and, as a result, have a greater tourist value, they can limit the efficiency of agricultural production on farms functioning on them. The possible difficulties include spatial dispersion of arable fields and difficult access to them, as well as potential production losses resulting from greater amount of weeds in agricultural crops and greater activity of wild animals on these areas.

In Poland, the Natura 2000 network, which covers $19.6 \%$ of the area of Poland, is to protect, in the first place, the biodiversity (Habuda, 2017) ${ }^{2}$. However, Poland has a much greater potential of areas relevant for the protection of biodiversity. It is indicated by the Natural And Tourist Value Index (NTVI) determined by the Institute of Soil Science and Plant Cultivation - State Research Institute (IUNG-PIB) for gminas in Poland. The index represents the average share of the total area of permanent grassland, forests, water, wetlands and other areas not subjected to anthropopressure in the total area in the surroundings of all utilised agricultural areas (UAA) of a given gmina within $2 \mathrm{~km}^{3}$. The average NTVI for gminas in Poland is $35.6 \%$ out of the possible $100 \%$, and for gminas with the NTVI $\geq 35.6 \%$, the average value of this index is $49.4 \%$. It should be added that the area of gminas with the NTVI $\geq 35.6 \%$ constitutes $57.7 \%$ of the area of Poland, and those gminas have $67.5 \%$ of permanent grassland, $75.9 \%$ of forests and $70.1 \%$ of water in Poland (Łopatka, Koza and Siebielec, 2017) .

\footnotetext{
${ }^{1}$ The more so because unfavourable changes in the agricultural landscape are still progressing in the European Union (EU), which is indicated by the Common Farmland Bird Index. Between 1990 and 2014, it decreased 31.5 percentage points (pp), including in 2004-2014, 11.4 pp (Eurostat).

${ }^{2}$ Natura 2000 sites consist of areas with special bird and habitat protection (Council Directive 92/43/EEC and Directive 2009/147/EC of the European Parliament and Council). The Natura 2000 network covers $18.1 \%$ of the EU area. Slovenia has the largest share (37.9\%), and Denmark the smallest (8.3\%) (Komisja Europejska, 2017).

${ }^{3}$ It should be emphasised that the natural value of a given area is conditioned by both the degree of its saturation with valuable natural habitats and the degree of their dispersion on a given area. It is worth adding that smaller dispersion of valuable natural habitats on a given area facilitates the migration of wild animals.

${ }^{4}$ At the request of the Ministry of Agriculture and Rural Development (MARD), the IUNG-PIB determined the NTVI for communes and cadastral regions as part of work on the new delimitation of less favoured areas (LFA), type specific handicaps in Poland after 2018. The need to carry out these works resulted from the guidelines of the European Commission and the provisions of the Regulation (EU) No. 1305/2013
} 
Taking into account the European Commission's findings on the need to strengthen the role of the agricultural sector in the protection of biodiversity in the EU financial perspective after 2020 and the significant share of areas relevant for the protection of biodiversity in Poland, it is reasonable to assess the functioning of farms from these areas.

\section{Objective of research, sources and method}

The purpose of the article is to assess the functioning of farms from gminas with high natural values with the Natural And Tourist Value Index (NTVI) equal to or greater than the national average $(35.6 \%)$ against the background of farms from other gminas, which kept accounting for the Polish FADN in 2015. In addition to the Natura 2000 biodiversity protection areas in Poland, valuable natural habitats are also located outside these areas ${ }^{5}$. What is more, in this context it is necessary to emphasise, inter alia, the role of afforestation and forests, which support the maintenance of many species of flora and fauna in the landscape and are important channels of migration of wild animals. In the light of the foregoing, the assessment of farms from gminas with high natural values against the background of farms from other gminas used the NTVI, which also takes into account areas with high natural values located outside Natura 2000 sites.

The analysis covered 8494 farms keeping accounting for the Polish FADN in 2015. Then, these farms were divided into two groups. The first one comprised 3937 (46.4\%) farms with agricultural production in gminas with the NTVI $\geq 35.6 \%$, hereinafter referred to as farms from gminas with high natural values. The second group covered 4557 (53.6\%) other farms. Within its framework, two sub-groups which significantly differed in natural farming conditions, i.e. soil quality, water conditions, the lay of the land and climate for farming, were identified. The first sub-group of farms comprised 1474 farms from gminas with worse natural farming conditions, i.e. with an average Agricultural Production Space Valuation Ratio (APSVR) below the national average (66.8 points) (farms from other gminas I), while the second -3083 farms from gminas with better natural farming conditions, i.e. with an average APSVR at the level of at least the national average (farms from

of the European Parliament and the Council according to which the separation of LFA specific handicaps should concern areas not only affected by specific constraints, but also when it is necessary for land management to be continued in order, e.g. to conserve the environment and preserve the tourist potential of the area. Importantly, according to the current European Commission's guidelines, delimitation of LFA with specific handicaps cannot be performed on the basis of demographic criteria. It should also be added that the NTVI was used in the works currently carried out by the IUNG-PIB and the Institute of Agricultural and Food Economics - National Research Institute (IERiGŻ-PIB) for the Ministry of Agriculture and Rural Development regarding the designation of High Nature Value (HNV) farmland in Poland (Jadczyszyn et al., 2018; Łopatka et al., 2017; Rozporządzenie Parlamentu Europejskiego i Rady nr 1305/2013).

${ }^{5}$ As part of Package 5: Valuable habitats outside Natura 2000 sites, being part of the agri-environment-climate in the RDP 2014-2020, 16.4 thousand farms on the area of approx. 125.5 thousand ha are financed (concerning commitments from the RDP 2007-2013 and new commitments from the RDP 2014-2020) (as at 31 Dec. 2016) (unpublished data of the ARMA and MARD). 
other gminas II) ${ }^{6}$. Finally, the comparative analysis covered farms from gminas with high natural values and farms from other gminas I and II.

It was decided that the analysis would not to include farms with intensive production organisation, where the impact of valuable natural areas on the obtained effects is usually small. In this type of farms, livestock production often takes place with a large share of purchased feed, whereas crop production (horticulture and permanent crops) often using shelter and irrigation ${ }^{7}$.

As mentioned in the introduction, the average NTVI for gminas in Poland is $35.6 \%$, and for gminas with high natural values $-49.4 \%$ (Map 1, Table 1). In gminas with high natural values, the average share of permanent grassland in utilised agricultural area is $33.6 \%$, while the share of forests and water in the total area is $38.1 \%$ and $2.9 \%$, respectively. On the other hand, in other gminas the situation in terms of the average NTVI is much worse. In other gminas I, this index amounts to $27.5 \%$, and in other gminas II $-22.4 \%$. In their case, the average share of permanent grassland in utilised agricultural area is $18.1 \%$ and $14.0 \%$, respectively, the share of forests in total area is $18.6 \%$ and $13.6 \%$, respectively, and the share of water is $1.6 \%$ and $1.7 \%$, respectively.

Table 1

The average Natural And Tourist Value Index (NTVI), the share of permanent grassland in utilised agricultural area and the share of forests and water in the total area in gminas with high natural values and other gminas I and II in Poland

\begin{tabular}{lcccc}
\hline \multicolumn{1}{c}{ Gminas } & $\begin{array}{c}\text { NTVI } \\
(\%)\end{array}$ & $\begin{array}{c}\text { Share of permanent grassland } \\
\text { in utilised agricultural area }(\%)\end{array}$ & $\begin{array}{c}\text { Share of forests } \\
\text { in total area }(\%)\end{array}$ & $\begin{array}{c}\text { Share of water } \\
\text { in total area (\%) }\end{array}$ \\
\hline $\begin{array}{l}\text { With high } \\
\text { natural values }\end{array}$ & 49.4 & 33.6 & 38.1 & 2.9 \\
Other I & 27.5 & 18.1 & 18.6 & 1.6 \\
Other II & 22.4 & 14.0 & 13.6 & 1.7 \\
\hline
\end{tabular}

Source: own study based on data from the IUNG-PIB.

\footnotetext{
${ }^{6}$ The APSVR takes into account factors affecting the quality of natural farming conditions, such as: soil quality, water conditions, the lay of the land and climate for farming. Each of them was assigned a weight proportional to its impact on crop yields. The APSVR calculated as the sum of these factors can reach a maximum of 120 points (Jadczyszyn et al., 2013).

${ }^{7}$ Farms with intensive production organisation were those which in 2015 exceeded the threshold value of at least one of three separated technical and organisational indicators (the stocking density equal to or greater than $1.0 \mathrm{LU}$ per 1 ha of utilized agricultural area, the share of permanent crops in utilized agricultural area equal to or greater than $37.2 \%$, the share of horticulture crops in utilized agricultural area equal to or greater than $17.4 \%$ ). The method of separating farms with intensive production organisation is described in detail in the study entitled Description and results of the fine-tuning procedure's application in Poland (Józwiak, Kagan and Zieliński, 2017) and Aktualizacja metody wyznaczania gospodarstw i obszarów o ekstensywnej produkcji rolnej w ramach HNV wraz z obszarami charakterystycznymi dla HNV (wariant II ) (Zieliński, Sobierajewska and Kagan, 2017).
} 


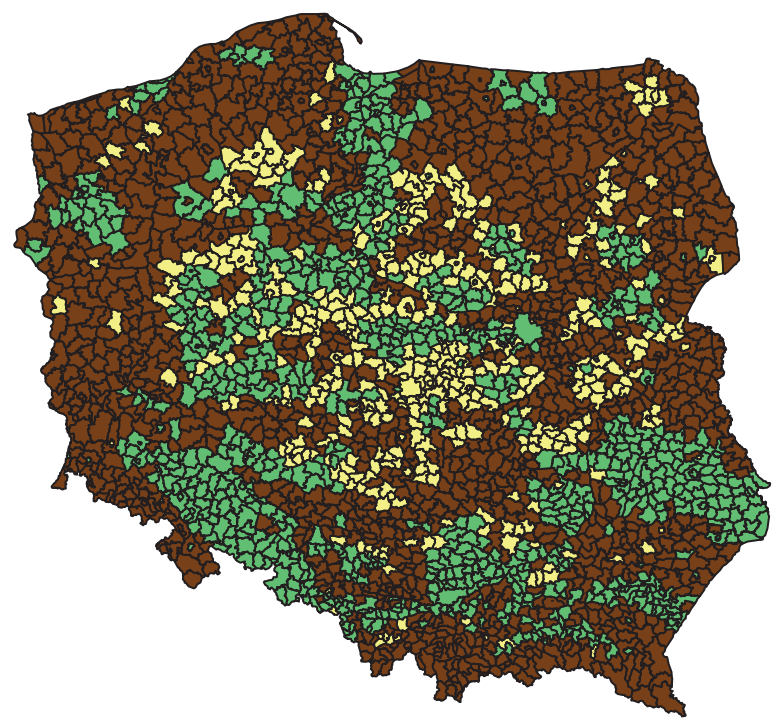

$\square$ Gminas with high natural values

Other gminas I

(with APSVR $<66.8$ points)

Other gminas II

(with APSVR $>=66.8$ points)

Map 1. The distribution of gminas with high natural values and other gminas I and II in Poland. Source: own study based on data from the IUNG-PIB.

In order to assess the functioning of separate groups of farms, the analysis included:

1) Production potential:

- utilised agricultural area expressed in ha, which consists of: own land, land leased for one year or more, land used on the basis of a share in crops with the owner, as well as fallow land;

- own soil bonitation index (points);

- share of farms located on LFA (\%);

- total labour input per 1 ha of utilised agricultural area, including total human labour input as part of the farm's operating activity in hours;

- the average value of capital per 1 AWU (Annual Work Unit) (PLN thousand/ AWU);

2) Organisation of production:

- the share of arable land in utilised agricultural area (\%);

- the share of cereals in arable lands (\%);

- the share of wheat in crops sown (\%);

- the share of permanent grassland in utilised agricultural area (\%);

- the stocking density expressed in livestock units per 1 ha of arable land (LU/ha AL);

3) Total production structure, production intensity, productivity, economic situation and investment opportunities:

- the structure of total production on the farm was determined as the share of crop, livestock and other production in total production (\%); 
- total costs, including direct costs, general economic costs, costs of depreciation and external factors per 1 ha of utilised agricultural area (PLN thousand/ ha of UAA);

- land productivity (PLN thousand/ha of UAA) determined as the ratio of total production value on the farm to the utilised agricultural area;

- capital productivity $(\%)$ determined as the ratio of total production value on the farm to the average capital value;

- labour productivity (PLN thousand/AWU) determined as the ratio of total production value to the number of annual work units;

- farm income per $1 \mathrm{FWU}$ (Family Work Unit) (PLN thousand) ${ }^{8}$;

- the share of operating subsidies in farm income (\%);

- the net investment rate $(\%)$ determined as the relation of net investments to depreciation.

\section{The structure of the analysed farms from gminas with high natural values and farms from other gminas I and II}

The analysis of the structure of farms from gminas with high natural values and from other gminas I and II was prepared according to the economic size expressed in EUR thousand of standard output (SO) and type of farming (TF 8).

On farms from gminas with high natural values and other gminas I, the distribution of the percentage structure of farms according to the economic size expressed in EUR thousand of SO was almost identical (Figure 1). In both cases, farms with an economic size up to EUR 25 thousand of SO had smaller shares, 37.0\% and $36.7 \%$ of all farms, respectively. Farms from other gminas II had slightly smaller share of farms with an economic size up to EUR 25 thousand of SO (33.3\%).

It was determined that the majority of farms from gminas with high natural values and farms from other gminas I are those rearing herbivorous animals in general $^{9}$ and in multilateral production (Fig. 2). In their case, the share of farms with field crops was smaller. On other farms II, this situation was quite different. This group was dominated by farms with field crops, while those with multilateral production and rearing herbivorous animals had a smaller share. The share of farms with horticulture and permanent crops as well as rearing granivorous animals in three analysed groups of farms was negligible.

\footnotetext{
${ }^{8}$ The analysis determined whether these farms in terms of income per 1 FWU and income without operating subsidies per 1 AWU were statistically significantly different. The significance of the differences was investigated using the non-parametric Mann-Whitney U test. This test was used because the distribution of the compared variables deviated from the normal distribution (Shapiro-Wilk test for $\mathrm{p}<\alpha=0.05$ ) (Stanisz, 2007a; 2007b).
}

${ }^{9}$ This applies to dairy cows and other herbivorous animals. 


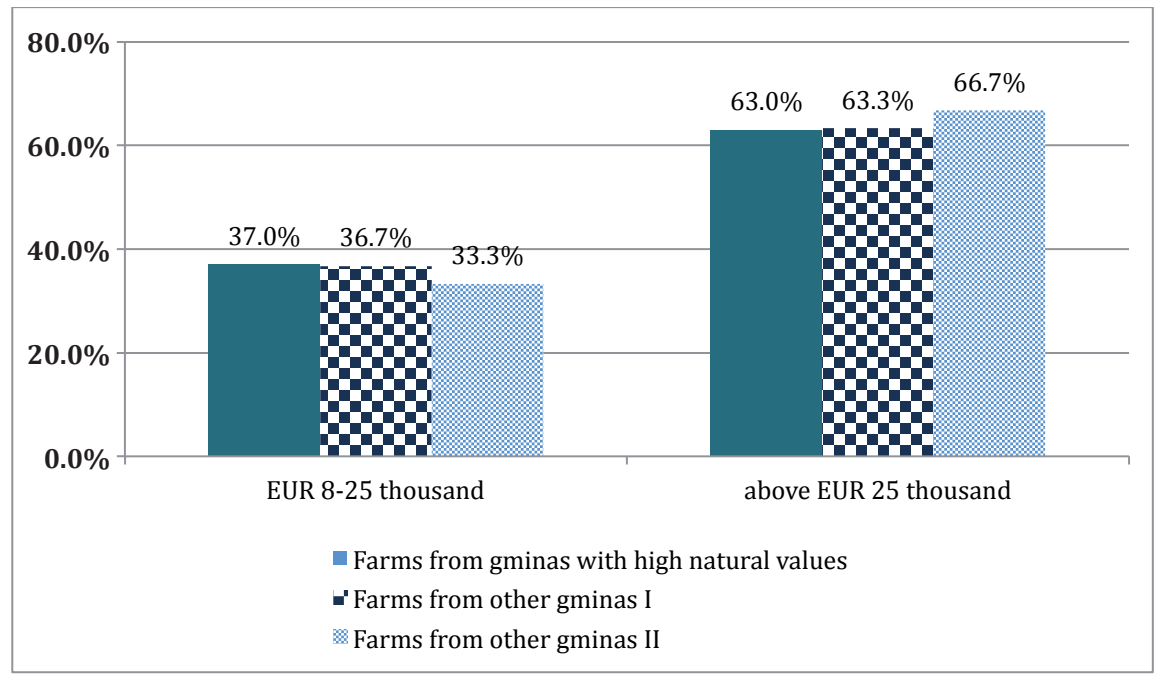

Fig. 1. Percentage structure of the analysed farms from gminas with high natural values and farms from other gminas I and II in 2015 according to their economic size (EUR thousand of SO). Source: own study based on data from the Polish FADN for 2015.

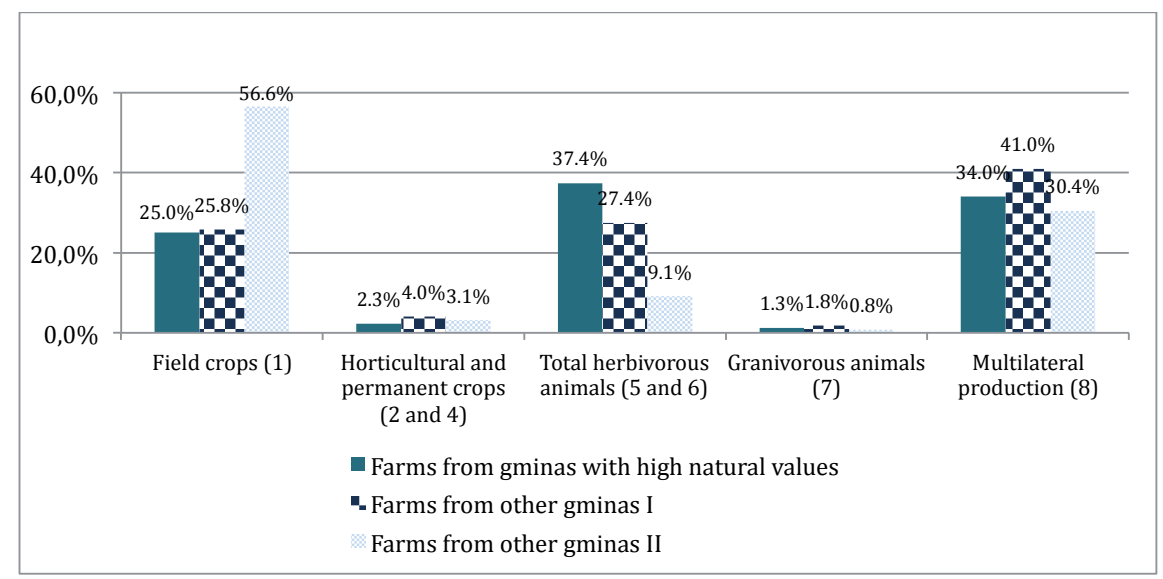

Fig. 2. Percentage structure of the analysed farms from gminas with high natural values and farms from other gminas I and II in 2015 according to the type of farming (TF8).

Source: as in Figure 1. 


\section{Research results}

The analysis of farms from gminas with high natural values against the background of farms from other gminas I and II indicated differences in the production potential, although the direction of these differences was different (Table 2). On farms from gminas with high natural values, the utilised agricultural area was $22.3 \%$ higher than on farms from other gminas I. They also had $20 \%$ less labour input per 1 ha of utilised agricultural area and $8.0 \%$ higher average capital value per 1 AWU. However, the direction of these differences was different in the comparison of farms from gminas with high natural values with those from other gminas II. Farms from gminas with high natural values had 7.2\% less utilised agricultural area, $10.1 \%$ greater labour input per 1 ha of utilised agricultural area and $10.9 \%$ lower average capital value per 1 AWU.

Farms from gminas with high natural values and from other gminas I compared to farms from other gminas II had significantly worse quality of land (Table 2). In their case, the own soil bonitation index was 0.6 and 0.7 , respectively, and was $45.5 \%$ and $36.4 \%$, respectively, lower than the soil bonitation index on farms from other gminas II. What is more, it was also $25.0 \%$ and $12.5 \%$ respectively, lower than the national average (0.8). ${ }^{10}$ This relation was confirmed in the share of farms located on LFA. On farms from gminas with high natural values and from other gminas I, their share amounted to $83.6 \%$ and $85.3 \%$, respectively, while on farms from other gminas II $-12.8 \%$.

Table 2

The production potential of the analysed farms from gminas with high natural values and farms from other gminas I and II in 2015

\begin{tabular}{lcccc}
\hline \multirow{2}{*}{ Detailed list } & \multirow{2}{*}{$\begin{array}{c}\text { Unit } \\
\text { of measure }\end{array}$} & $\begin{array}{c}\text { Farms from gminas } \\
\text { with high natural } \\
\text { values }\end{array}$ & \multicolumn{2}{c}{ Farms from other gminas: } \\
\cline { 5 - 5 } $\begin{array}{l}\text { UAA } \\
\text { Total labour input } \\
\text { per 1 ha of UAA }\end{array}$ & ha & 38.9 & 31.8 & II \\
$\begin{array}{l}\text { The average value of capital } \\
\text { per 1 AWU }\end{array}$ & $\begin{array}{c}\text { PLN } \\
\text { hour/ha of UAA }\end{array}$ & 98.1 & 122.7 & 89.1 \\
$\begin{array}{l}\text { Own soil bonitation index } \\
\text { The share of farms }\end{array}$ & points & 299.0 & 276.8 & 335.7 \\
located on LFA & $\%$ & 0.6 & 0.7 & 1.1 \\
\hline
\end{tabular}

Source: as in Figure 1.

Comparison of production organisation shows that the share of arable land in utilised agricultural area on farms from gminas with high natural values was clearly smaller compared to farms from other gminas, and cereals had slightly smaller share in the structure of arable land. Moreover, due to worse soil conditions, farms

\footnotetext{
${ }^{10}$ According to the Central Statistical Office of Poland, the average soil bonitation index is 0.8 (GUS, 2012).
} 
from gminas with high natural values and from other gminas I compared to farms from other gminas II had a significantly smaller share of wheat in the structure of cereal cultivation areas (Table 3 ).

Farms from gminas with high natural values had a larger share of permanent grassland in utilised agricultural area (Table 3). The situation was different in the case of stocking density calculated in livestock units (LU) per 1 ha of arable land. In this case, the stocking density on farms from gminas with high natural values was identical to the one on farms from other gminas I, although definitely larger than on the farms from other gminas II. This is justified because the poor quality of soils on farms from gminas with high natural values and other gminas I more often incline farmers to establish permanent grassland and rear animals fed with roughage. As a result, these farms use animal manure, which can improve the fertility of their soil, to a greater extent.

Table 3

Chosen characteristics of production organisation on the analysed farms from gminas with high natural values and on farms from other gminas I and II in 2015

\begin{tabular}{|c|c|c|c|c|}
\hline \multirow{2}{*}{ Detailed list } & \multirow{2}{*}{$\begin{array}{l}\text { Unit of } \\
\text { measure }\end{array}$} & \multirow{2}{*}{$\begin{array}{c}\text { Farms from gminas } \\
\text { with high natural } \\
\text { values }\end{array}$} & \multicolumn{2}{|c|}{$\begin{array}{l}\text { Farms from } \\
\text { other gminas: }\end{array}$} \\
\hline & & & I & II \\
\hline $\begin{array}{l}\text { Share of arable land in utilised } \\
\text { agricultural area, including: }\end{array}$ & & 76.3 & 87.8 & 93.1 \\
\hline $\begin{array}{l}\text { - share of cereals in arable land, } \\
\text { including: }\end{array}$ & $\%$ & 63.7 & 66.5 & 64.1 \\
\hline - share of wheat in the cereal structure & & 28.9 & 22.6 & 56.5 \\
\hline $\begin{array}{l}\text { Share of permanent grassland } \\
\text { in utilised agricultural area }\end{array}$ & $\%$ & 22.4 & 11.3 & 5.1 \\
\hline $\begin{array}{l}\text { Stocking density per } 1 \text { ha } \\
\text { of arable land }\end{array}$ & LU & 0.7 & 0.7 & 0.3 \\
\hline
\end{tabular}

Source: as in Figure 1.

In the case of farms from gminas with high natural and other I, the share of animal production in total production amounted to $47.8 \%$ and $43.4 \%$, respectively, and crop production $-50.9 \%$ and $55.8 \%$, respectively. Farms from other gminas II were characterised by a definitely different production structure. In their case, the share of crop production in total production was $78.8 \%$, and animal production $20.2 \%$ (Table 4 ). 
Table 4

Total production structure on the analysed farms from gminas with high natural values and on farms from other gminas I and II in 2015

\begin{tabular}{lcccc}
\hline \multicolumn{1}{c}{ Detailed list } & $\begin{array}{c}\text { Unit of } \\
\text { measure }\end{array}$ & $\begin{array}{c}\text { Farms from gminas } \\
\text { with high } \\
\text { natural values }\end{array}$ & \multicolumn{2}{c}{ Farms from other gminas: } \\
\cline { 4 - 5 } $\begin{array}{l}\text { Share of livestock production } \\
\text { in total production }\end{array}$ & $\%$ & 47.8 & I & II \\
\hline $\begin{array}{l}\text { Share of crop production } \\
\text { in total production }\end{array}$ & $\%$ & 50.9 & 53.4 & 20.2 \\
$\begin{array}{l}\text { Share of other production } \\
\text { in total production }\end{array}$ & $\%$ & 1.3 & 0.8 & 1.0 \\
\hline
\end{tabular}

Source: as in Figure 1.

On the basis of data from Table 5, it can be concluded that the production intensity was lower on farms from gminas with high natural values. On these farms, total costs per 1 ha of utilised agricultural area were lower $17.1 \%$ compared to farms from other gminas. This applied to all basic categories of costs, i.e. direct, general economic, depreciation and of external factors.

Table 5

Production intensity on the analysed farms from gminas with high natural values and farms from other gminas I and II in 2015

\begin{tabular}{lcccc}
\hline \multirow{2}{*}{ Detailed list } & \multirow{2}{*}{$\begin{array}{c}\text { Unit } \\
\text { of measure }\end{array}$} & $\begin{array}{c}\text { Farms from gminas } \\
\text { with high natural } \\
\text { values }\end{array}$ & \multicolumn{2}{c}{ Farms from other gminas: } \\
\cline { 5 - 6 } Total costs, including: & PLN thousand/ha & 3.4 & 4.1 & II \\
- direct costs & PLN thousand/ha & 1.7 & 2.1 & 2.1 \\
- general economic costs & PLN thousand/ha & 0.8 & 0.9 & 0.9 \\
- depreciation & PLN thousand/ha & 0.7 & 0.8 & 0.8 \\
- costs of external factors & PLN thousand/ha & 0.2 & 0.3 & 0.3 \\
\hline
\end{tabular}

Source: as in Figure 1.

An important criterion for the assessment of the analysed farms is also the productivity of production factors. It turned out that compared to farms from other gminas I, farms from gminas with high natural values had $13.3 \%$ less land productivity. The opposite situation occurred in the case of labour and capital productivity. It turned out that in this respect farms from gminas with high natural values had an advantage of $9.1 \%$ and $0.3 \mathrm{pp}$, respectively. As far as the productivity of production factors is concerned, the situation of farms from gminas with high natural values was much worse than farms from other gminas II. In this case, the former had $20.4 \%, 26.9 \%$ and 6.2 pp lower productivity of land, labour and capital, respectively (Table 6). 
Table 6

Productivity of production factors in the analysed farms from gminas with high natural values and farms from other gminas I and II in 2015

\begin{tabular}{lcccc}
\hline \multirow{2}{*}{ Detailed list } & \multirow{2}{*}{$\begin{array}{c}\text { Unit } \\
\text { of measure }\end{array}$} & $\begin{array}{c}\text { Farms from gminas } \\
\text { with high } \\
\text { natural values }\end{array}$ & \multicolumn{2}{c}{ Farms from other gminas: } \\
\cline { 5 - 6 } Land productivity & PLN thousand/ha & 3.9 & 4.5 & II \\
Labour productivity & PLN thousand/AWU & 85.5 & 78.4 & 117.0 \\
Capital productivity & $\%$ & 28.6 & 28.3 & 34.8 \\
\hline
\end{tabular}

Source: as in Figure 1.

The above differences characterising the analysed groups of farms are important reasons for the differences in their incomes per 1 FWU. Income per $1 \mathrm{FWU}$ on farms from gminas with high natural values was $14.7 \%$ higher than on farms from other gminas I, and 32.2\% lower than on farms from other gminas II (Table 7). In both cases, the difference was statistically significant. The attention is also drawn to the fact that on farms from gminas with high natural values and from other gminas I against the background of farms from other gminas II, this income was obtained to a larger extent due to received subsidies to operating activity. In these farms, the share of operating subsidies in income amounted to $73.6 \%, 74.4 \%$ and $59.1 \%$, respectively.

On farms from gminas with high natural values and from other gminas II, income per 1 FWU provided payment for the owner's work and work of his family members at the parity level corresponding to the average net annual salary in the national economy ${ }^{11}$. In these farms, income per 1 FWU was $7.45 \%$ and $58.3 \%$ higher, respectively, than the parity income. However, an opposite direction of this difference occurred on farms from other gminas I, where this income was $6.4 \%$ lower than the parity income.

The investment activity of farms from gminas with high natural values was high enough to be characterised by a positive net investment rate, which amounted to $8.0 \%$ (Table 7). However, it was much smaller than on farms from other gminas II, where it amounted to $33.9 \%$. In this respect, farms from other gminas were in a poor situation, with a negative net investment rate $(-12.3 \%)$.

\footnotetext{
${ }^{11}$ In 2015, the average net salary in the national economy amounted to PLN 31.2 thousand (Żekało, Abramczuk, Czułowska and Jabłoński, 2016).
} 
Table 7

Economic situation, the share of subsidies on farm income and development opportunities of the analysed farms from gminas with high natural values and farms from other gminas I and II in 2015.

\begin{tabular}{lcccc}
\hline \multirow{2}{*}{ Detailed list } & $\begin{array}{c}\text { Unit } \\
\text { of measure }\end{array}$ & $\begin{array}{c}\text { Farms from gminas } \\
\text { with high natural } \\
\text { values }\end{array}$ & \multicolumn{2}{c}{ Farms from other gminas: } \\
\cline { 5 - 6 } Farm income per 1 FWU & PLN thousand & 33.5 & 29.2 & II \\
$\begin{array}{l}\text { The share of operating subsidies } \\
\text { in farm income }\end{array}$ & $\%$ & 73.6 & 74.4 & 59.1 \\
Net investment rate & $\%$ & 8.0 & -12.3 & 33.9 \\
\hline
\end{tabular}

Source: as in Figure 1.

\section{Summary and conclusions}

Taking into account the European Commission's findings to date regarding the need to strengthen the role of the agricultural sector in the protection of biodiversity in the next EU financial perspective (CAP after 2020), a comparative analysis of farms from gminas with high natural values against the background of farms from other gminas was performed. The analysis covered three groups of farms which kept accounting for the Polish FADN in 2015. The first group consisted of farms from gminas with high natural values with the Natural And Tourist Value Index (NTVI) equal to or greater than the national average (35.6\%). On the other hand, the second group were farms from other gminas with worse natural farming conditions, i.e. with the Agricultural Production Space Valuation Ratio (APSVR) lower than the national average (66.8 pt.) (farms from other gminas I), whereas the third were farms from other gminas with the APSVR equal to or greater than the national average (farms from other gminas II). The comparative analysis took into account the production potential of farms, production organisation, production intensity, productivity of production factors, farm income per $1 \mathrm{FWU}$, share of subsidies in farm income and the net investment rate.

Based on the analysis, it was established that:

- Against the background of farms from other gminas I, farms from gminas with high natural values have a larger area and slightly worse quality of utilised agricultural area. They bear less total labour input per 1 ha of utilised agricultural area and have a higher average value of capital per 1 AWU. In addition, these farms bear lower costs, have lower land productivity, but higher productivity of labour and capital. They achieve significantly higher income per $1 \mathrm{FWU}$ and it is large enough to ensure payment for owner's work and work of his family members at the over-parity level. These farms also have a positive net investment rate, while on farms being a reference point it is negative.

- In comparison with farms from other gminas II, farms from gminas with high natural values have a smaller and much worse quality of UAA. They bear greater 
total labour input per 1 ha of utilised agricultural area and have a lower average value of capital per $1 \mathrm{AWU}$. They bear lower costs and achieve lower productivity of basic production factors. Moreover, they have significantly lower income per $1 \mathrm{FWU}$, and this difference is large enough to be statistically significant. Even though they have a positive net investment rate, the scale of these investments is clearly smaller than in the case of farms used for comparisons.

The analysis showed that despite impediments having a negative effect on the economic situation of farms from gminas with high natural values, they provide payment for the owner's work and work of his family members at the over-parity level and see opportunities for further development for themselves. However, it should be emphasised that these opportunities are definitely worse than on farms from gminas with natural farming conditions at the level of at least average for Poland. It should also be added that the Polish FADN collects accountancy data from economically stronger farms against the background of all farms in Poland. Therefore, it should be assumed that the presented development opportunities of farms from gminas with high natural values reflect development opportunities only of farms with high production potential. In the case of farms with lower production potential, which usually serve their managers as an additional source of income (auxiliary farms), these opportunities are probably even smaller. 


\section{References}

Dyrektywa Parlamentu Europejskiego i Rady 2009/147/WE z dnia 30 listopada 2009 r. w sprawie ochrony dzikiego ptactwa.

Dyrektywa Rady 92/43/EWG z dnia 21 maja 1992 r. w sprawie ochrony siedlisk przyrodniczych oraz dzikiej fauny i flory.

Habuda, A. (2017). Obszary Natura 2000 w prawie polskim, czeskim i słowackim. Analiza porównawcza. Warszawa: Wydawnictwo Difin.

Jadczyszyn, J., Kopiński, J., Kuś, J., Łopatka, A., Madej, A., Matyka, M., Musiał, W., Siebielec, G. (2013). Rolnictwo na obszarach specyficznych. Powszechny Spis Rolny 2010. Warszawa: GUS.

Jadczyszyn, J., Brzezińska, K., Feledyn-Szewczyk, B., Horabik, D., Józwiak, W., Kagan, A., Krogulec, J., Kujawa, K., Piórkowski, H., Sobierajewska, J., Stalenga, J., Zieliński, M. (2018). Wyznaczenie potencjalnych obszarów HNV Farmland w oparciu o rozszerzony zakres komponentów środowiska przyrodniczego i obszary ekstensywnej produkcji rolnej. Prezentacja dla MRiRW, MRiRW, Warszawa, 24.01.2018.

Józwiak, W., Kagan, A., Zieliński, M. (2017). Description and results of the fine-tuning procedure's application in Poland. Raport IERiGŻ-PIB dla Komisji Europejskiej, February 2017.

Komisja Europejska (2017). Biuletyn o przyrodzie i różnorodności biologicznej. Natura 2000. No. 42, July 2017.

Komunikat Komisji do Parlamentu Europejskiego, Rady, Europejskiego Komitetu Ekonomicznego - Społecznego i Komitetu Regionów pt. Przyszłość rolnictwa i produkcji żywności. European Commision, Brussels, 29 November 2017 COM(2017) 713 final.

Łopatka, A., Koza, P., Siebielec, G. (2017). Propozycja metodyki wydzieleń zasięgów obszarów ONW typ specyficzny wg tzw. kryteriów krajowych. Ekspertyza dla MRiRW, January 2017.

GUS (2012 ). Rocznik Statystyczny Rolnictwa. Warszawa: GUS.

Rozporządzenie Parlamentu Europejskiego i Rady nr 1305/2013 z dnia 17 grudnia 2013 r. w sprawie wsparcia rozwoju obszarów wiejskich przez Europejski Fundusz Rolny na rzecz Rozwoju Obszarów Wiejskich (EFRROW) i uchylające rozporządzenie Rady (WE) no. 1698/2005.

The future of food \& farming. Protecting the environment \& tackling climate change. Fact Sheet. CAP and the environment. Komisja Europejska, 29 Novwmber 2017.

Stanisz, A. (2007a). Przystepny kurs statystyki z zastosowaniem STATISTICA PL na przykładach z medycyny. T. 2. Modele liniowe i nieliniowe. Kraków: Statsoft.

Stanisz, A. (2007b). Przystepny kurs statystyki z zastosowaniem STATISTICA PL na przykładach z medycyny. T. 3. Analizy wielowymiarowe. Kraków: Statsoft.

Wäckers, F. (2017). Increasing biodiversity and profitability. Prezentacja z konferencji "The 2017 EU Agricultural Outlook". European Commision, Brussels, 18-19 December 2017.

Zieliński, M., Sobierajewska, J., Kagan, A. (2017). Aktualizacja metody wyznaczania gospodarstw i obszarów o ekstensywnej produkcji rolnej w ramach HNV wraz z obszarami charakterystycznymi dla HNV (wariant II). Ekspertyza IERiGŻ-PIB dla MRiRW, September 2017.

Ziętara, W., Adamski, M. (2017). Konkurencyjność polskich gospodarstw mlecznych i z chowem bydła rzeźnego na tle analogicznych gospodarstw z wybranych krajów. In: W. Józwiak (ed.), Przedsiębiorstwo i gospodarstwo rolne wobec zmian klimatu i polityki rolnej (3) Program Wieloletni 2015-2019, no. 51 (pp. 77-125). Warszawa: IERiGŻ-PIB.

Żekało, M., Abramczuk, Ł., Czułowska, M., Jabłoński, K. (2016). Produkcja, koszty i dochody z wybranych produktów rolniczych w latach 2014-2015. Warszawa: IERiGŻ-PIB. 
Data of Eurostat: www.ec.europa.eu/eurostat/web/products-datasets/-/t2020_rn130.

Data of Institute of Soil Science and Plant Cultivation (IUNG) in Puławy (access date: 17.03.2017). Data of Polish FADN: www.fadn.pl. 


\title{
FUNKCJONOWANIE GOSPODARSTW Z OBSZARÓW \\ O DUŻYCH WALORACH PRZYRODNICZYCH \\ NA TLE GOSPODARSTW POZOSTAEYCH
}

\begin{abstract}
Abstrakt
Celem opracowania jest ocena funkcjonowania gospodarstw z gmin o du$\dot{z} y c h$ walorach przyrodniczych na tle gospodarstw z gmin pozostałych $w$ Polsce. Za gminy o dużych walorach przyrodniczych uznano te, w których ustalony przez Instytut Uprawy Nawożenia i Gleboznawstwa - PIB (IUNG-PIB) - wskaźnik cenności przyrodniczo-turystycznej (WCPT) wynióst co najmniej $35,6 \%$ na $100 \%$ możliwych do osiagnięcia. W analizie porównawczej wzięto pod uwage potencjał produkcyjny gospodarstw, organizacje produkcji, ponoszone koszty, produktywności czynników produkcji, dochód z gospodarstwa rolnego $w$ przeliczeniu na $1 \mathrm{FWU}$, udziat dopłat operacyjnych $w$ dochodzie z gospodarstwa rolnego oraz stope inwestycji netto. Analize wykonano korzystajac $z$ danych gospodarstw rolnych prowadzacych rachunkowość dla Polskiego FADN w 2015 roku $i$ z danych IUNG-PIB. Ustalono, że gospodarstwa $z$ gmin o dużych walorach przyrodniczych $i$ prowadzace rachunkowość dla Polskiego FADN w 2015 roku m.in. zapewniały opłate pracy własnej właściciela i członków jego rodziny na poziomie ponad parytetowym oraz widziały dla siebie możliwości dalszego rozwoju.
\end{abstract}

Słowa kluczowe: gospodarstwo rolne, cenność przyrodnicza, WPR po 2020 roku, dochód z gospodarstwa rolnego, stopa inwestycji netto.

Accepted for print: 5.09.2018.

Unless stated otherwise all the materials on the website are available under the Creative Commons Attribution 4.0 International license.

Some rights reserved to the Institute of Agricultural and Food Economics - National Research Institute.

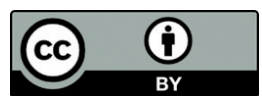

